Sport Science: Jurnal Sain Olahraga dan Pendidikan Jasmani ISSN 114-562X (Cetak), ISSN XXXX-XXXX(Online)

http://sportscience.ppj.unp.ac.id/index.php/jss/index

\title{
Kontribusi Kecepatan dan Daya Ledak terhadap Hasil Lompat Jauh pada Siswa SMP Negeri 2 Lengayang
}

\author{
Yan Sofian Anwar ${ }^{1}$, Asep Sujana Wahyuri², Sefri Hardiansyah ${ }^{3}$ \\ ${ }^{123}$ Fakultas Ilmu Keolahragaan, Universitas Negeri Padang, Indonesia.
}

E-mail: yansofian@yahoo.com ${ }^{1}, \underline{\text { sefrihardiansyah@,fik.unp.ac.id }}{ }^{2}, \underline{\text { asepsw@,fik.unp.ac.id }^{3}}$

\begin{abstract}
Abstrak
Jauhnya hasil lompatan pada olahraga lompat jauh dipengaruhi oleh beberapa faktor diantaranya faktor kondisi fisik. Faktor kondisi fisik itu sendiri diantaranya kecepatan dan daya ledak. Untuk mencapai hasil lompatan yang sejauh-jauhnya dalam lompat jauh dipengaruhi oleh kecepatan dalam melakukan awalan dan daya ledak saat melakukan tolakan. Berdasarkan pemikiran tersebut, maka dirumuskan masalah dalam penelitian ini, yaitu seberapa besar kontribusi kecepatan dan daya ledak terhadap hasil lompat jauh pada siswa SMP Negeri 2 Lengayang Kabupaten Pesisir Selatan.

Penelitian ini tergolong pada jenis penelitian kuantitatif dengan menggunakan teknik analisis korelasional dengan tujuan melihat kontribusi dua variabel bebas, yaitu kecepatan $\left(\mathrm{X}_{1}\right)$ dan daya ledak $\left(\mathrm{X}_{2}\right)$ terhadap variabel terikatnya hasil lompat jauh (Y) siswa SMP Negeri 2 Lengayang Kabupaten Pesisir Selatan. Penelitian ini dilakukan di SMP Negeri 2 Lengayang Kabupaten Pesisir.

Berdasarkan perhitungan korelasi diperoleh: 1) terdapat hubungan yang signifikan antara kecepatan $\left(\mathrm{X}_{1}\right)$ dengan hasil lompat jauh $(\mathrm{Y})$ siswa putra yang diperoleh $\mathrm{T}$ hitung $=9,567>\mathrm{T}$ tabel $=$ 1,6720. 2) tidak terdapat hubungan yang signifikan antara daya ledak otot tungkai $\left(\mathrm{X}_{2}\right)$ dengan hasil lompat jauh $(\mathrm{Y})$ siswa putra yang diperoleh $\mathrm{T}$ hitung $=0,507<\mathrm{T}$ tabel $=1,6720.3)$ terdapat hubungan yang signifikan antara kecepatan $\left(\mathrm{X}_{1}\right)$ dan daya ledak otot tungkai $\left(\mathrm{X}_{2}\right)$ secara bersama-sama dengan hasil lompat jauh $(\mathrm{Y})$ siswa putra hal ini ditandai dengan diperoleh $\mathrm{F}$ hitung $=71,82>\mathrm{F}$ tabel $=3,15$. 4) terdapat hubungan yang signifikan antara kecepatan $\left(\mathrm{X}_{1}\right)$ dengan hasil lompat jauh $(\mathrm{Y})$ siswa putri diperoleh $\mathrm{T}$ hitung $=3,084>\mathrm{T}$ tabel $=1,8964$. 5) tidak terdapat hubungan yang signifikan antara daya ledak otot tungkai $\left(\mathrm{X}_{2}\right)$ dengan hasil lompat jauh $(\mathrm{Y})$ siswa putri yang diperoleh $\mathrm{T}$ hitung $=1,282<\mathrm{T}$ tabel $=1,8946$. 6) terdapat hubungan yang signifikan antara kecepatan $\left(\mathrm{X}_{1}\right)$ dan daya ledak otot tungkai $\left(\mathrm{X}_{2}\right)$ secara bersama-sama dengan hasil lompat jauh $(\mathrm{Y})$ siswa putri hal ini ditandai dengan diperoleh $\mathrm{F}$ hitung $=7,2334>\mathrm{F}$ tabel $=4,74$.
\end{abstract}

Kata kunci: Kecepatan, Daya ledak, Lompat Jauh

\begin{abstract}
The results of the leap on a long jump sport are influenced by factors such as the physical condition factor. Factors of physical condition itself include speed and explosive power. To achieve the Sejauh-jauhnya leap result in a long jump is influenced by the speed in the prefix and the explosive power when performing the recharging. Based on the thought, then formulated the problem in this research, that is how big the contribution of speed and explosive power to the results of a long jump in junior high students 2 Lengayang district South Coast.

This research is classified into quantitative research using correlational analytical techniques with the intention to see the contribution of two free variables, namely the speed (XI) and explosive Power (X2) on the variable the result of the long jump (Y) of junior high school students 2 Lengayang district South Coast. This research was conducted at SMP Negeri 2 Lengayang South Coastal District.

Based on the correlation calculation obtained: 1) There is a significant relationship between the speed (XI) with the result of distant jump (Y) students acquired T count $=9.567>$ T table $=1.6720 .2$ )
\end{abstract}


There is not a significant relationship between the power of the leg muscles (X2) with the result of the long jump (Y) The student of the son acquired T count $=0.507<T$ table $=1.6720 .3)$ There is a significant relationship between the speed (X1) and the muscular power of the limbs (X2) together with the result of distant jump $(Y)$ students of this matter is characterized by acquired $f$ count $=71.82$ $>f$ table $=3.15 .4)$ There is a significant relationship between the speed (XI) with far jump results (y) student daughter acquired t count $=1.89643 .084$ 5) There is no significant relationship between the muscle-explosive power of the limbs (X2) with the results of the distant jump (Y) the student daughter acquired T count $=1.282<$ T table $=1.8946 .6)$ There is a significant relationship between the speed (X1) and the muscular power of the limbs (X2) together with the far jump result (Y) students of the daughter it is characterized by the acquired $F$ count $=7.2334>F$ table $=4.74$.

Keywords: speed, explosive power, far jump

\section{PENDAHULUAN}

Pembinaan berbagai cabang olahraga melalui kegiatan ekstrakurikuler telah masuk ke dalam Kurikulum Tingkat Satuan Pendidikan (KTSP) melalui pengembangan silabus dan Rencana Pelaksanaan Pembelajaran (RPP) dengan tujuan agar peserta didik dapat mencapai Standar Kompetensi (SK) dan Kompetensi Dasar (KD) mulai dari tingkat Sekolah Dasar (SD), Sekolah Menengah Pertama (SMP) sampai Sekolah Menengah Atas (SMA). Kegiatan kejuaraan olahraga di tingkat pelajar telah menjadi kalender tahunan bagi pemerintah untuk memperoleh bibit yang berprestasi dari usia dini. Kejuaraan olahraga yang diadakan di antaranya: OOSN (Olympiade Olahraga Siswa Nasional) untuk tingkat SD dan tingkat SMP, POPDA (Pekan Olahraga Pelajar Daerah untuk tingkat SMA dan kejuaraan lainnya.

Berisi jenis penelitian, waktu dan tempat penelitian, target/sasaran, subjek penelitian, prosedur, instrumen dan teknik analisis data serta hal-hal lain yang berkait dengan cara penelitiannya. target/sasaran, subjek penelitian, prosedur, data dan instrumen, dan teknik pengumpulan data, serta teknik analisis data serta hal-hal lain yang berkait dengan cara penelitiannya dapat ditulis dalam subsubbab, dengan sub-subheading. Sub-subjudul tidak perlu diberi notasi, namun ditulis dengan huruf kecil berawalkan huruf kapital, TNR-11 unbold, rata kiri.

Khususnya untuk penelitian kualitatif, waktu dan tempat penelitian perlu dituliskan secara jelas (untuk penelitian kuantitatif, juga perlu).Target/subjek penelitian (untuk penelitian kualitatif) atau populasi-sampel (untuk penelitian kuantitatif) perlu diurai dengan jelas dalam bagian ini. Perlu juga dituliskan teknik memperoleh subjek (penelitian kualitatif) dan atau teknik samplingnya (penelitian kuantitatif). Prosedur perlu dijabarkan menurut tipe penelitiannya. Bagaimana penelitian dilakukan dan data akan diperoleh, perlu diuraikan dalam bagian ini.

Berbicara mengenai prestasi, cabang olahraga atletik nomor lompat jauh di SMP Negeri 2 Lengayang Kabupaten Pesisir Selatan dilakukan pembinaan melalui kegiatan ekstrakurikuler olahraga sejak tahun 2000. Hasil wawancara penulis dengan guru pendidikan jasmani, olahraga dan kesehatan SMP Negeri 2 Lengayang Kabupaten Pesisir Selatan, bahwa nomor lompat jauh kurang mengalami perkembangan yang baik sampai sekarang.

Setiap tes lompat jauh yang dilakukan melalui ujian semester dan kegiatan lomba class meeting, rata-rata siswa SMP Negeri 2 Lengayang Kabupaten Pesisir Selatan hanya mampu melompat sejauhjauhnya $3.5 \mathrm{~m}$. Disimpulkan, bahwa hasil lompat jauh siswa SMP Negeri 2 Lengayang Kabupaten Pesisir Selatan masih dalam kategori rendah di bawah standar lompatan maksimal yaitu $3.6 \mathrm{~s} / \mathrm{d} 5.2 \mathrm{~m}$. Adapun lompatan yang terjauh dicapai siswa dari setiap kejuaraan yang diikuti terhitung dari tahun 2007 sampai sekarang rata-rata siswa hanya mampu melakukan lompatan sejauh $3.8 \mathrm{~m}$.

Observasi penulis pada beberapa kali latihan, rendahnya hasil lompat jauh siswa SMP Negeri 2 Lengayang Kabupaten Pesisir Selatan disebabkan oleh beberapa faktor, diantaranya: kemampuan fisik siswa yang rendah terutama kurangnya kecepatan siswa melakukan awalan dan kurang kuatnya tubuh 
melakukan tolakan (daya ledak) dalam melakukan lompatan. Penguasaan teknik lompat jauh yang kurang baik, ketersediaan sarana dan prasarana yang kurang memadai dalam latihan, minat dan bakat siswa yang kurang, motivasi siswa yang rendah dalam latihan, dan kualitas pembina dalam melakukan pembinaan.

Sebagaimana yang telah diuraikan pada bagian terdahulu bahwa untuk dapat melakukan lompat jauh dengan baik, seseorang pelompat harus menguasai teknik-teknik seperti: menolak, melayang dan mendarat. Menolak merupakan hal yang paling utama dalam melakukan lompat jauh, karena dengan tolakan yang kuat akan dapat menghasilkan lompatan yang jauh. Untuk mencapai kemampuan lompat jauh sejauh-jauhnya diperlukan kondisi fisik yang baik terutama dari kemampuan kecepatan dan daya ledak.

Sesuai teori, selain menguasai teknik lompat jauh dengan baik, kecepatan dan tolakan (daya ledak) merupakan komponen kondisi yang paling utama dalam mencapai hasil lompatan yang sejauhjauhnya. Makin cepatnya awalan yang dilakukan dan kuatnya tubuh dalam melakukan tolakan, maka akan makin maksimal hasil yang diperoleh dari lompat jauh yang dilakukan. Disimpulkan, bahwa kecepatan dan tolakan (daya ledak) memiliki kontribusi yang positif dalam mencapai hasil lompat jauh dengan jarak sejauh-jauhnya.

Dari beberapa faktor di atas sesuai teori, bahwa faktor yang dominan mempengaruhi hasil lompat jauh adalah kecepatan dan daya ledak. Kecepatan dan daya ledak memegang peranan yang sangat penting terhadap hasil lompat jauh, namun belum diketahui seberapa besar kontribusinya terhadap hasil lompat jauh. Untuk mendapatkan gambaran yang akurat dan terarah mengenai permasalahan di atas, perlu dilakukan suatu penelitian yang lebih mendalam mengenai masalah ini. Dengan demikian penelitian ini nantinya diharapkan mampu menggambarkan data-data yang mendekati kearah benar.

\section{METODE}

Penelitian ini tergolong pada penelitian kuantitatif dengan menggunakan teknik analisis korelasional yang dilanjutkan dengan menghitung besarnya kontribusi variabel bebas terhadap variabel terikatnya. Adapun variabel yang dihubungkan dalam penelitian ini adalah Kecepatan $\left(\mathrm{X}_{1}\right)$, Daya Ledak otot tungkai $\left(\mathrm{X}_{2}\right)$ sebagai variabel bebas dengan Hasil lompat jauh $(\mathrm{Y})$ sebagai varibel terikatnya. Penelitian ini dilakukan di SMP Negeri 2 Lengayang Kabupaten Pesisir selatan. Mengingat lompat jauh yang dipelajari pada kurikulum pembelajaran pendidikan jasmani, olahraga dan kesehatan di kelas VIII SMP yang dilanjutkan dengan kegiatan ektrakurikuler, maka populasi dalam penelitian ini adalah siswa kelas VIII SMP Negeri 2 Lengayang Kabupaten Pesisir Selatan. Untuk lebih jelasnya dapat dilihat pada tabel 1 berikut ini:

\begin{tabular}{ccccc}
\multicolumn{5}{c}{ Tabel 1. Populasi Penelitian } \\
\hline NO & Kelas & Putra & Putri & Jumlah \\
\hline 1 & VIII A & 7 & 27 & 34 \\
2 & VIII B & 14 & 18 & 32 \\
3 & VIII C & 17 & 16 & 33 \\
4 & VIII D & 15 & 17 & 32 \\
5 & VIII E & 19 & 16 & 35 \\
Jumlah & $\mathbf{7 2}$ & $\mathbf{9 4}$ & $\mathbf{1 6 6}$
\end{tabular}

Teknik pengambilan sampel adalah purposive sampling yaitu siswa putra dan putri SMP Negeri 2 Lengayang Kabupaten Pesisir Selatan yang aktif dalam ekstrakurikuler atletik saat penelitian dilakukan, dengan jumlah 60 orang siswa putra dan 10 orang siswa putri.

\section{Teknik Pengumpulan Data dan Pengukuran Data}

Untuk mendapatkan data dalam penelitian ini terlebih dahulu penulis membuat beberapa langkah kerja yaitu: 
a. Mendapatkan surat izin penelitian dari Dekan Fakultas Ilmu Keolahragaan Universitas Negeri Padang.

b. Menyiapkan alat-alat serta perlengkapan tes kecepatan lari, Tes daya ledak dan tes lompat jauh. Adapun alat-alat yang digunakan yaitu:

1) Papan Vertical Jump (untuk mengukur daya ledak otot tungkai)

2) Stop Watch (untuk mengukur kecepatan lari)

3) Meteran (untuk mengukur hasil lompatan)

4) Pluit (untuk aba-aba pada saat melakukan penelitian)

5) Bendera Star (untuk aba-aba pada saat melakukan penelitian)

6) Blangko Tes (untuk pencatatan hasil penelitian)

7) Alat tulis (untuk pencatatan hasil penelitian)

8) Serbuk kapur (untuk tanda tinggi lompatan)

9) Bak lompat jauh (untuk tes lompat jauh)

10) Cangkul (untuk perbaikan permukan bak lompat jauh)

c. Menyiapkan tenaga pembantu yang bertugas untuk mencatat skor dan menghitung pelaksanaan tes pada waktu pengambilan data dibutuhkan 3 orang.

d. Persiapan Format Data

Sebelum mengambil data terlebih dahulu disiapkan format isian tes yang diperlukan untuk mempermudah dalam pencatatan data dan menghindari terjadinya kelebihan data. Pengukuran data dilaksanakan dengan melakukan tes terhadap siswa yang dijadikan sampel. Dalam penelitian ini dibutuhkan 2 jenis data yaitu data variabel bebas $(\mathrm{X})$ dan varibel terikat $(\mathrm{Y})$. Adapun varibel bebas adalah Kecepatan $\left(\mathrm{X}_{1}\right)$, Daya Ledak otot tungkai $\left(\mathrm{X}_{2}\right)$, sedangkan variabel terikat adalah Hasil Lompat Jauh (Y). pengambilan data dilakukan sebagai berikut:

\section{a. Kecepatan}

Menurut Zatsyorskiy dalam Wilis, 2003, kecepatan maksimum dicapai setelah 30 meter dan dapat dipelihara sampai 60 meter. Sesuai dengan penjelasan di atas maka tes kecepatan lari menggunakan jarak 40 meter.Hasil yang dicatat adalah waktu yang dicapai oleh tester dari 2 kali kesempatan dan waktu terbaik yang digunakan untuk pengolahan data, dengan satuan sampai 10 detik.

Table 3. Norma Lari 30 Meter (Putra)

\begin{tabular}{clc}
\hline No & \multicolumn{1}{c}{ Norma } & Prestasi (detik) \\
\hline 1 & Baik Sekali & $3.58-3.91$ \\
2 & Baik & $3.92-4.34$ \\
3 & Sedang & $4.35-4.72$ \\
4 & Kurang & $4.73-5.11$ \\
5 & Kurang Sekali & $5.12-5.50$ \\
\hline
\end{tabular}

Sumber. Perkembangan Olahraga Terkini, Jakarta, 2003.

Table 4. Norma Lari 30 Meter (Putri)

\begin{tabular}{clc}
\hline No & \multicolumn{1}{c}{ Norma } & Prestasi (detik) \\
\hline 1 & Baik Sekali & $4.06-4.50$ \\
2 & Baik & $4.51-4.96$ \\
3 & Sedang & $4.97-5.40$ \\
4 & Kurang & $5.41-5.86$ \\
5 & Kurang Sekali & $5.87-6.30$ \\
\hline \multicolumn{2}{l}{ Sumber: } & Perkembangan Olahraga Terkini, Jakarta, 2003
\end{tabular}

\section{b. Daya Ledak dengan Vertical Jump Test}

Eksplosive Power (daya ledak) Otot Tungkai diukur berdasarkan hasil tes dengan pelaksanaan vertical jump test. Nilai yang diperoleh testi adalah selisih yang terbanyak antara tinggi loncatan dengan tinggi raihan dari ketiga loncatan yang dilakukan. (Ismaryati, 2008:69). 


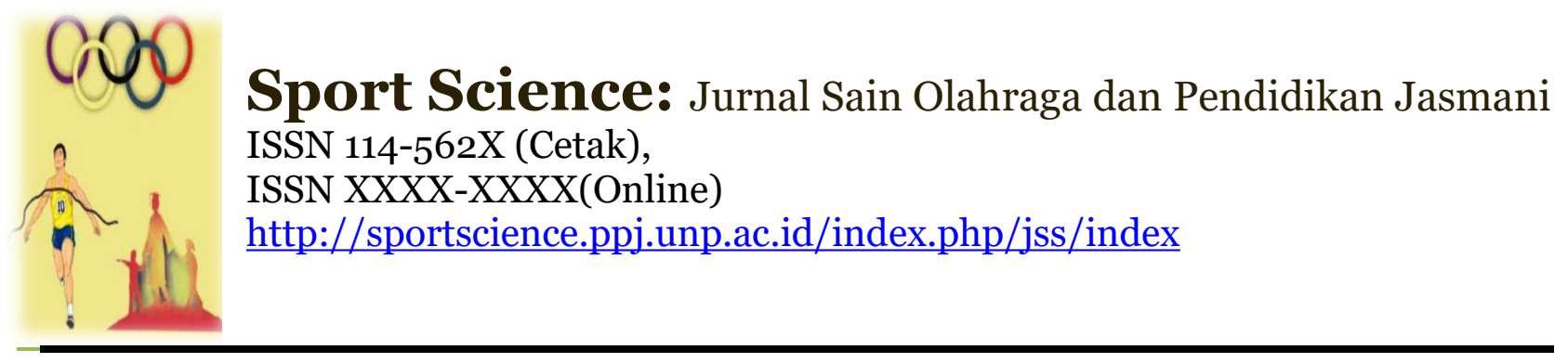

Tabel 5. Norma Loncat Tegak Putra dan Putri

\begin{tabular}{cccc}
\hline \multicolumn{2}{c}{ Prestasi (cm) } & \multicolumn{2}{c}{ Nilai } \\
Putra & Putri & Putra & Putri \\
\hline$>89$ & $>63$ & 10 & 10 \\
$85-88$ & $60-63$ & 9 & 9 \\
$81-85$ & $56-59$ & 8 & 8 \\
$76-80$ & $53-55$ & 7 & 7 \\
$71-75$ & $49-52$ & 6 & 6 \\
$66-70$ & $46-48$ & 5 & 5 \\
$60-65$ & $41-45$ & 4 & 4 \\
$50-59$ & $36-40$ & 3 & 3 \\
$40-49$ & $31-35$ & 2 & 2 \\
$<40$ & $<30$ & 1 & 1 \\
\hline
\end{tabular}

\section{c. Lompat Jauh}

Untuk melihat hasil lompat jauh dapat dilakukan dengan cara testee diberi kesempatan untuk melakukan lompat jauh dengan menggunakan awalan $30 \mathrm{~s} / \mathrm{d} 40$ meter dicatat sebagai hasil lompat jauh yang dihitung dengan satuan senti meter. Teknik pengukuran hasil lompat jauh dilakukan dari batas balok tumpuan sebelah dalam hingga ke batas terdekat jatuhnya tester (Jonath, 1987). Hasil Lompatan terjauh dari 2 kali melakukan lompatan itulah yang di pakai untuk pengolahan data.

Table 6. Norma Prestasi Lompat Jauh (meter) Putra

\begin{tabular}{cccc}
\hline Umur & Memuaskan & Baik & Sangat Baik \\
\hline $13-14$ & 3.6 & 4.2 & 4.6 \\
$15-16$ & 4.2 & 4.7 & 5.2 \\
\hline
\end{tabular}

Sumber: Atletik untuk Sekolah, 1991.

Table 7. Norma Prestasi Lompat Jauh (meter) Putri

$\begin{array}{cccc}\text { Umur } & \text { Memuaskan } & \text { Baik } & \text { Sangat Baik } \\ 13-14 & 3.1 & 3.8 & 4.0 \\ 15-16 & 3.6 & 4.0 & 4.2\end{array}$

Sumber: Atletik untuk Sekolah, 1991

Berdasarkan pada hipotesis yang diajukan, analisis data yang dilakukan dengan menggunakan statistik analisis korelasi berganda (Multiple Correlation). Sebelum data dianalisis terlebih dahulu dilakukan uji normalitas dengan uji Liliefors dan uji Linieritas persamaan regresi pada taraf signifikan 0,05 . Analisis korelasi berganda digunakan untuk membuktikan penelitian yang diajukan, adapun rumus korelasi berganda tersebut menggunakan rumus korelasi product moment oleh Pearson dalam Muhidin dan Maman (2007:132). Uji signifikan korelasi menurut Sudjana (1992), dilakukan untuk mengetahui apakah yang telah dihitung melalui koefisien itu signifikan atau tidak.

\section{HASIL DAN PEMBAHASAN \\ Hasil Penelitian}

Setelah dilakukan penelitian pada siswa SMP Negeri 2 Lengayang Kabupaten Pesisir Selatan, maka dapat dideskripsikan data yang didapat seperti pada Tabel 4.1.

Tabel 8. Deskrispi Data Penelitian Putra dan Putri

\begin{tabular}{lcccccc}
\hline \multirow{1}{*}{ Variabel } & \multicolumn{3}{c}{ Kecepatan (detik) } & \multicolumn{2}{c}{$\begin{array}{c}\text { Daya Ledak Otot } \\
\text { Tungkai (kg.m) }\end{array}$} & \multicolumn{2}{c}{$\begin{array}{c}\text { Lompat Jauh } \\
\text { (m) }\end{array}$} \\
& Putra & Putri & Putra & Putri & Putra & Putri \\
\hline Nilai tertinggi & 5.81 & 5.66 & 11.95 & 9.52 & 5.10 & 4.25 \\
Nilai Terendah & 3.90 & 4.24 & 6.10 & 6.34 & 3.05 & 3.10 \\
Rata-rata & 4.80 & 4.92 & 8.65 & 8.30 & 3.79 & 3.60 \\
\hline
\end{tabular}




\begin{tabular}{lllllll}
\hline Median & 4.89 & 5.03 & 8.63 & 8.46 & 3.69 & 3.63 \\
Simpangan Baku & 0.55 & 0.46 & 1.25 & 1.06 & 0.52 & 0.39 \\
\hline
\end{tabular}

\section{Variabel Kecepatan}

\section{a. Variabel kecepatan putra}

Hasil penelitian menunjukkan rentang kecepatan (X1) adalah antara 5.81 detik sampai 3.90 dengan rata-rata 4.92 dan median sebesar 4.98 dan simpangan baku sebesar 0,55. Distribusi frekuensi dapat dilihat pada table 4.2 berikut

Tabel 9. Distribusi Frekuensi Kecepatan (X1) Putra

\begin{tabular}{lccc}
\hline \multirow{2}{*}{ Kategori } & Interval & \multicolumn{2}{c}{ Frekuensi } \\
& Kelas & Absolute & Relatif (\%) \\
\hline Baik Sekali & $3.58-3.91$ & 1 & 1.7 \\
Baik & $3.92-4.34$ & 18 & 30 \\
Sedang & $4.35-4.72$ & 9 & 15 \\
Kurang & $4.73-5.11$ & 11 & 18.3 \\
Kurang Sekali & $>5.12$ & 21 & 35 \\
$\quad$ Jumlah & Jumlah & 60 & 100 \\
\hline
\end{tabular}

Berdasarkan tabel 4.2, terlihat testee yang berada pada kategori baik sekali hanya 1 orang $(1.7 \%)$, yang berada di kategori baik sebanyak 18 orang $(30 \%)$, dan testee terbanyak berada pada kategori kurang sekali yaitu sebanyak 21 (35\%).

\section{b. Variabel kecepatan putri}

Hasil penelitian menunjukkan rentang kecepatan $\left(\mathrm{X}_{1}\right)$ untuk atlet putri adalah antara 5.66 detik sampai 4.24 dengan rata-rata 4.92 dan median sebesar 5.03 dan simpangan baku sebesar 0.46 . Distribusi frekuensi dapat dilihat pada table 4.2 berikut:

Tabel 10. Distribusi Frekuensi Kecepatan (X1) Putri

\begin{tabular}{cccc}
\hline Kategori & $\begin{array}{c}\text { Interval } \\
\text { Kelas }\end{array}$ & Absolute & Rrekuensi \\
& $4.06-4.50$ & 2 & 20 \\
Baik Sekali & $4.51-4.96$ & 2 & 20 \\
Baik & $4.97-5.40$ & 5 & 50 \\
Sedang & $5.41-5.86$ & 1 & 10 \\
Kurang & $5.78-6.30$ & - & - \\
Kurang Sekali & & 10 & 100 \\
Jumlah & & & Relatif \\
\hline
\end{tabular}

Berdasarkan tabel 4.3 , terlihat sebanyak 5 orang (50\%) testee berada pada kategori sedang, sedangkan pada kategori baik sekali dan baik masing-masing ada 2 orang dan 1 orang testee $(10 \%)$ berada pada kategori kurang.

\section{Variabel Daya Ledak Otot Tungkai}

\section{a. Variabel daya ledak otot tungkai putra}

Hasil penelitian menunjukkan daya ledak otot tungkai putra (X2) adalah antara $6.10 \mathrm{~kg} . \mathrm{m}$ sampai dengan 11.95 kg.m rata-rata 8.65 dan median sebesar 8.63 dan simpangan baku sebesar 1.25. Distribusi frekuensi dapat dilihat pada table 4.3 berikut:

Tabel 11. Distribusi Frekuensi Daya Ledak Otot Tungkai (X2) Putra

\begin{tabular}{ccc}
\hline \multirow{2}{*}{ Interval Kelas } & \multicolumn{2}{c}{ Frekuensi } \\
& Absolute & Relatif (\%) \\
\hline $6.10-7.10$ & 6 & 10 \\
$7.11-8.11$ & 14 & 23.3 \\
$8.12-9.12$ & 21 & 35 \\
$9.13-10.13$ & 12 & 20 \\
\hline
\end{tabular}


Sport Science: Jurnal Sain Olahraga dan Pendidikan Jasmani ISSN 114-562X (Cetak), ISSN XXXX-XXXX(Online)

http://sportscience.ppj.unp.ac.id/index.php/jss/index

\begin{tabular}{crr}
$10.14-11.14$ & 4 & 6.7 \\
$11.14-12.14$ & 3 & 5 \\
jumlah & 60 & 100 \\
\hline
\end{tabular}

Berdasarkan tabel 4.3, dibandingkan dengan nilai rata-rata, terlihat testee yang berada pada kelas rata-rata sebanyak 21 orang $(35 \%)$ dan yang berada di bawah kelas rata-rata sebanyak 20 orang $(33,3 \%)$, sedangkan testee yang berada di atas kelas rata-rata sebanyak 19 orang $(31,7 \%)$.

\section{b. Variabel daya ledak otot tungkai putri}

Hasil penelitian menunjukkan Daya Ledak Otot Tungkai putri (X2) adalah antara 6.34 kg.m sampai dengan $9.52 \mathrm{~kg} . \mathrm{m}$ rata-rata 8.65 dan median sebesar 8.46 dan simpangan baku sebesar 1.06 . Distribusi frekuensi dapat dilihat pada table 4.3 berikut:

Tabel 12. Distribusi Frekuensi Daya Ledak Otot Tungkai (X2) Putri

\begin{tabular}{ccc}
\hline \multirow{2}{*}{ Interval Kelas } & \multicolumn{2}{c}{ Frekuensi } \\
& Absolute & Relatif (\%) \\
\hline $6.34-7.04$ & 1 & 10 \\
$7.05-7.75$ & 2 & 20 \\
$7.76-8.46$ & 2 & 20 \\
$8.47-9.17$ & 2 & 20 \\
$9.18-9.88$ & 3 & 30 \\
jumlah & 10 & 100 \\
\hline
\end{tabular}

Berdasarkan tabel 4.4, dibandingkan dengan nilai rata-rata, terlihat testee yang berada pada kelas rata-rata sebanyak 2 testee $(20 \%)$ dan yang berada di bawah kelas rata-rata sebanyak 5 testee $(50 \%)$, sedangkan testee yang berada di atas kelas rata-rata sebanyak 3 testee (30

\section{Variabel Lompat Jauh (Y)}

\section{a. Variabel lompat jauh putra (Y)}

Hasil penelitian menunjukkan rentang lompat jauh (Y) adalah antara $3.05 \mathrm{~m}$ sampai $5.10 \mathrm{~m}$ dengan rata-rata 3.79 dan median 3.69 dengan simpangan baku sebesar 0.52 dan varian 0.27 .

Distribusi frekuensi dapat dilihat pada table 4.4 berikut:

Tabel 13. Distribusi Frekuensi Lompat Jauh (Y) Putra

\begin{tabular}{lcc}
\hline \multirow{2}{*}{ Interval Kelas } & \multicolumn{2}{c}{ Frekuensi } \\
& Absolute & Relatif (\%) \\
\hline $3.05-3.35$ & 17 & 28.3 \\
$3.36-3.66$ & 12 & 20 \\
$3.67-3.97$ & 8 & 13.3 \\
$3.98-4.28$ & 14 & 23.3 \\
$4.29-4.59$ & 5 & 8.3 \\
$4.60-4.90$ & 2 & 3.3 \\
$4.91-5.21$ & 2 & 3.3 \\
Jumlah & 60 & 100 \\
\hline
\end{tabular}

Berdasarkan tabel 4.5, dibandingkan dengan nilai rata-rata, terlihat testee yang berada pada kelas rata-rata sebanyak 8 orang $(13,3 \%)$ dan yang berada di bawah kelas rata-rata 29 orang $(48,3 \%)$, sedangkan testee yang berada di atas kelas rata-rata sebanyak 23 orang $(38,2 \%)$.

\section{b. Variabel lompat jauh putri (Y)}

Hasil penelitian menunjukkan rentang lompat jauh (Y) untuk putri adalah antara $3.10 \mathrm{~m}$ sampai $4.25 \mathrm{~m}$ dengan rata-rata 3.60 dan median 3.63 dengan simpangan baku sebesar 0.39.

Distribusi frekuensi dapat dilihat pada table 4.4 berikut:

\section{Tabel 14. Distribusi Frekuensi Lompat Jauh (Y) Putri \\ Interval Kelas \\ Frekuensi}

$$
\text { Absolute Relatif (\%) }
$$




$\begin{array}{crr}3.10-3.40 & 4 & 40 \\ 3.41-3.71 & 2 & 20 \\ 3.72-4.02 & 3 & 30 \\ 4.03-4.33 & 1 & 10 \\ \text { Jumlah } & 10 & 100\end{array}$

Berdasarkan tabel 4.6, dibandingkan dengan nilai rata-rata, terlihat testee yang berada pada kelas rata-rata sebanyak 2 orang $(20 \%)$ dan yang berada di bawah kelas rata-rata hanya 4 testee $(40 \%)$, sedangkan testee yang berada di atas kelas rata-rata sebanyak 4 orang (40\%).

\section{Pengujian Persyaratan Analisis}

Hipotesis pada penelitian ini di uji dengan menggunakan analisis korelasi product moment dan dilanjutkan uji t untuk koefisien korelasi parsial dan uji $\mathrm{F}$ untuk koefisien korelasi ganda. Untuk menggunakan teknik ini ada beberapa persyaratan yang harus dipenuhi diantaranya menurut Sudjana adalah data berasal dari populasi yang berdistribusi normal.

\section{Uji Normalitas}

Pengujian normalitas variable kecepatan (X1), daya ledak otot tungkai (X2), dan lompat jauh (Y) dianalisis dengan Liliefors dengan Ho jika Lo $<$ Lt maka data berdistribusi normal, dan Ha jika Lo $>$ Lt maka data tidak berdistribusi normal. Untuk lebih jelasnya dapat dilihat hasil uji normalitas data pada table 4.7

Tabel 15. Hasil Uji Normalitas Data Putra

\begin{tabular}{llccc}
\hline No & \multicolumn{1}{c}{ Variable } & Lo & Lt 0,05 & Keterangan \\
\hline 1 & Kecepatan & 0.1413 & 0.1144 & Tidak Normal \\
2 & Daya Ledak Otot Tungkai & 0.0650 & 0.1144 & Normal \\
3 & Lompat Jauh & 0.0889 & 0.1144 & Normal \\
\hline
\end{tabular}

Dari table 4.7 terlihat bahwa variable kecepatan pada penelitian putra berdistribusi tidak normal $\left(\mathrm{Lo}>\mathrm{L}_{\text {tabel}}\right)$, maka uji statistik yag berikutnya digunakan adalah statistik non parametrik, dimana dalam hal ini pembuktian hipotesis penelitian dilakukan dengan analisis korelasi spearman.

Tabel 16. Hasil Uji Normalitas Data Putri

\begin{tabular}{llccc}
\hline No & \multicolumn{1}{c}{ Variable } & Lo & Lt 0,05 & Keterangan \\
\hline 1 & Kecepatan & 0.1273 & 0.258 & Normal \\
2 & Daya Ledak Otot Tungkai & 0.1251 & 0.258 & Normal \\
3 & Lompat Jauh & 0.1794 & 0.258 & Normal \\
\hline
\end{tabular}

Dari table 4.8 terlihat bahwa seluruh variable pada penelitian putri berdistribusi normal $\left(\right.$ Lo $\left.<\mathrm{L}_{\text {tabel }},\right)$, sehingga uji statistik yag berikutnya digunakan adalah statistik parametrik dimana dalam hal ini uji pembuktian hipotesis penelitian dengan menggunakan analisa korelasi ganda pearson.

\section{Pengujian Hipotesis}

1. Hubungan antara kecepatan $\left(X_{I}\right)$ dengan hasil lompat jauh $(Y)$ pada siswa putra SMP Negeri 2 Lengayang Kabupaten Pesisir Selatan.

Untuk menguji hipotesis ini dilakukan analisa korelasi parsial antara variable $\mathrm{X}_{1}$ dengan variable $Y$, jika dianggap $X_{2}$ tetap, dengan hipotesa analisa korelasinya adalah sebagai berikut: $\mathrm{H}_{0}=$ Tidak terdapat hubungan yang signifikan antara kecepatan dengan hasil lompat jauh $\mathrm{H}_{\mathrm{a}}=$ Terdapat hubungan yang signifikan antara kecepatan dengan hasil lompat jauh

Dari analisa korelasi parsial yang dilanjutkan dengan uji t didapatkanlah hasil seperti pada table berikut:

Tabel 17. Hasil Analisa Korelasi Parsial kecepatan $\left(X_{1}\right)$ dengan Hasil lompat jauh $(Y)$

\begin{tabular}{|c|c|c|c|c|c|}
\hline Sampel & Hubungan & Lambang & $\begin{array}{c}\text { Nilai } \\
\text { koefisien } \\
\text { korelasi }\end{array}$ & $\begin{array}{c}\text { Uji } \\
\text { keberartian } \\
\text { Koef. } \\
\text { Korelasi }\end{array}$ & $\begin{array}{c}\text { Nilai Kritis } \\
\text { Pada } \\
\text { Tabel } \alpha \\
5 \%\end{array}$ \\
\hline
\end{tabular}




Sport Science: Jurnal Sain Olahraga dan Pendidikan Jas
ISSN 114-562X (Cetak),
ISSN XXXX-XXXX(Online)
http://sportscience.ppj.unp.ac.id/index.php/jss/index

Dari table 4.9 terlihat bahwa untuk siswa putra nilai $r=0.785\left(r^{2}: 0,6162\right)$ dilanjutkan dengan uji t ternyata $t_{\text {hit }}: 9.567>t_{\text {tabel }}: 1.6720$. Hasil ini berarti hubungan antara kecepatan dengan hasil lompat jauh signifikan $\left(\mathrm{H}_{0}\right.$ ditolak $; \mathrm{H}_{\mathrm{a}}$ diterima) nilai koefesien korelasi 0.785 menyatakan tingkat keeratan hubungan adalah kuat. Begitu juga dengan siswa putri nilai $r=0.759\left(r^{2}: 0,5761\right)$ dilanjutkan dengan uji $t$ ternyata $t_{\text {hit }}: 3,084>t_{\text {tabel }}: 1.88946$. Hasil ini berarti hubungan antara kecepatan dengan hasil lompat jauh signifikan $\left(\mathrm{H}_{0}\right.$ ditolak $; \mathrm{H}_{\mathrm{a}}$ diterima) nilai koefesien korelasi 0.759 menyatakan tingkat keeratan hubungan adalah kuat. Dari nilai $\mathrm{r}^{2}$ dapat dinyatakan bahwa kecepatan berkontribusi sekitar 57,61\% - 61,62\% terhadap keberhasilan dalam lompat jauh, dimana kontribusi ini sangat berarti dalam peningkatan prestasi lompat jauh.

\section{Hubungan antara daya ledak otot tungkai $\left(\mathrm{X}_{2}\right)$ dengan hasil lompat jauh $(Y)$ pada siswa putra SMP Negeri 2 Lengayang Kabupaten Pesisir Selatan.}

Untuk menguji hipotesis ini dilakukan analisa korelasi parsial antara variable $\mathrm{X}_{2}$ dengan variable $Y$, jika dianggap $\mathrm{X}_{1}$ tetap, dengan hipotesa analisa korelasinya adalah sebagai berikut: $\mathrm{H}_{0}=$ Tidak terdapat hubungan yang signifikan antara daya ledak otot tungkai dengan hasil lompat jauh $\mathrm{H}_{\mathrm{a}}=$ Terdapat hubungan yang signifikan antara daya ledak otot tungkai dengan hasil lompat jauh

Dari analisa ini didapatkan nilai koefisien korelasi parsial antara daya ledak otot tungkai dengan hasil lompat jauh seperti pada table berikut:

Tabel 18. Analisa Korelasi Parsial daya ledak otot tungkai $\left(X_{2}\right)$ dengan hasil lompat jauh (Y)

\begin{tabular}{|c|c|c|c|c|c|}
\hline Sampel & Hubungan & Lambang & $\begin{array}{c}\text { Nilai } \\
\text { koefisien } \\
\text { korelasi }\end{array}$ & $\begin{array}{c}\text { Uji } \\
\text { keberartian } \\
\text { Koef. } \\
\text { Korelasi }\end{array}$ & $\begin{array}{c}\text { Nilai Kritis } \\
\text { Pada Tabel } \alpha \\
5 \%\end{array}$ \\
\hline Putra & $\begin{array}{l}\text { Hubungan antara daya ledak } \\
\text { otot tungkai }\left(\mathrm{X}_{2}\right) \text { dengan } \\
\text { hasil lompat jauh }(\mathrm{Y}) \text {, jika } \\
\text { kecepatan }\left(\mathrm{X}_{1}\right) \text { tetap }\end{array}$ & $r_{x_{1}\left(x_{2} y\right)}$ & 0.067 & $\mathrm{t}_{\text {hit }}=0.507$ & $\mathrm{t}_{\text {tabel }}=1.6720$ \\
\hline Putri & $\begin{array}{l}\text { Hubungan antara Kecepatan } \\
\left(\mathrm{X}_{1}\right) \text { dengan lompat jauh( }(\mathrm{Y}) \text {, } \\
\text { jika daya ledak otot tungkai } \\
\left(\mathrm{X}_{2}\right) \text { tetap }\end{array}$ & $r_{x_{1}\left(x_{2} y\right)}$ & 0.436 & $\mathrm{t}_{\text {hit }}=1.282$ & $\mathrm{t}_{\text {tabel }}=1.8946$ \\
\hline
\end{tabular}

Dari table 4.10 terlihat bahwa pada siswa putra nilai $r=0.067\left(\mathrm{r}^{2}: 0,0045\right)$ yang kemudian dilanjutkan dengan uji $\mathrm{t}$ dengan hasil $\mathrm{t}_{\text {hit }} 0.507<\mathrm{t}_{\text {tabel }} 1.6720$. Hasil ini menunjukkan bahwa tidak terdapat hubungan yang signifikan antara daya ledak otot tungkai dengan hasil lompat jauh. $\left(\mathrm{H}_{0}\right.$ diterima; $\mathrm{H}_{\mathrm{a}}$ ditolak) nilai koefesien korelasi 0.067 menyatakan tingkat keeratan hubungan adalah rendah. Seiring dengan siswa putra, nilai koefisien korelasi pada siswa putri adalah $r: 0,436\left(r^{2}\right.$ : 0,1900 ) yang kemudian dilanjutkan dengan uji t dengan hasil thit $1,282<t_{\text {tabel }} 1.8946$.

Hasil ini menunjukkan bahwa tidak terdapat hubungan yang signifikan antara daya ledak otot tungkai dengan hasil lompat jauh. Dari nilai $\mathrm{r}^{2}$ dapat dinyatakan bahwa daya ledak otot tungkai berkontribusi sekitar $0,45 \%$ - 19,0\% terhadap keberhasilan dalam lompat jauh, dimana kontribusi ini sangat kecil dalam peningkatan prestasi lompat jauh. 
3. Hubungan antara kecepatan $\left(X_{1}\right)$ dan daya ledak otot tungkai $\left(X_{2}\right)$ dengan hasil lompat jauh $(Y)$ pada siswa putra SMP Negeri 2 Lengayang kabupaten Pesisir Selatan.

Hipotesis ini dapat dianalisa dengan korelasi ganda (multiplied correlation), dimana sebelumnya dilakukan dulu analisa korelasi parsial antar variable. Korelasi parsial adalah suatu nilai yang memberikan kuatnya hubungan dua atau lebih variable $\mathrm{X}$ dengan variable $\mathrm{Y}$, yang salah satu bagian variable bebasnya dianggap konstan atau dibuat tetap. Setelah didapatkan nilai koefisian korelasi parsial maka baru dilanjutkan dengan analisa korelasi berganda yaitu suatu nilai yang memberikan kuatnya hubungan dua atau lebih variable bebas $\mathrm{X}$ secara bersama-sama dengan varibel tak bebas Y. Hipotesa untuk korelasi berganda dalam penelitian ini adalah:

$\mathrm{H}_{0}=$ Tidak terdapat hubungan yang signifikan antara kecepatan dan daya ledak otot tungkai secara bersama-sama dengan hasil lompat jauh

$\mathrm{H}_{\mathrm{a}}=$ Terdapat hubungan yang signifikan antara kecepatan dan daya ledak otot tungkai secara bersama-sama dengan hasil lompat jauh

Hasil dari analisa korelasi ganda dari variable kecepatan (X1), daya ledak otot tungkai (X2) dan hasil lompat jauh (Y) seperti dapat dilihat pada table berikut :

Tabel 19. Analisa Korelasi Linear, Korealsi Parsial dan Korelasi Ganda Variabel $X_{1}, X_{2}$ dan $Y$

\begin{tabular}{|c|c|c|c|c|c|}
\hline Sampel & Hubungan & Lambang & $\begin{array}{c}\text { Nilai } \\
\text { koefisien } \\
\text { korelasi }\end{array}$ & $\begin{array}{c}\text { Uji } \\
\text { keberartian } \\
\text { Koef. } \\
\text { Korelasi } \\
\end{array}$ & $\begin{array}{c}\text { Nilai Kritis } \\
\text { Pada Tabel } \\
\alpha 5 \%\end{array}$ \\
\hline Putra & $\begin{array}{l}\text { Hubungan antara kecepatan } \\
\left(\mathrm{X}_{1}\right) \text { dan daya ledak otot } \\
\text { tungkai }\left(\mathrm{X}_{2}\right) \text { secara bersama- } \\
\text { sama, dengan hasil lompat } \\
\text { jauh(Y) }\end{array}$ & $R_{x_{1} x_{2} y}$ & 0.819 & $F_{\text {hit }}=71.82$ & $\mathrm{~F}_{\text {tabel }}=3.15$ \\
\hline Putri & $\begin{array}{l}\text { Hubungan antara kecepatan } \\
\left(\mathrm{X}_{1}\right) \text { dan daya ledak otot } \\
\text { tungkai }\left(\mathrm{X}_{2}\right) \text { secara bersama- } \\
\text { sama, dengan hasil lompat } \\
\text { jauh(Y) }\end{array}$ & $R_{x_{1} x_{2} y}$ & 0.787 & $F_{\text {hit }}=7.23$ & $\mathrm{~F}_{\text {tabel }}=4.74$ \\
\hline
\end{tabular}

Dari table 4.11 dapat dilihat bahwa hubungan antara variable kecepatan dan daya ledak otot tungkai secara bersama-sama dengan hasil lompat jauh merupakan hubungan yang kuat antara variable bebas dengan variable tak bebas, dengan nilai koefisien korelasi ganda untuk putra $R: 0,819\left(R^{2}\right.$ : 0,6707) dan hasil uji keberartian koefisien korelasi ganda dengan uji $F$ yaitu $F_{\text {hit }}: 71,82>F_{\text {tabel }}: 3,15$, dan nilai koefisien korelasi ganda untuk putri $R: 0,787\left(R^{2}: 0,6194\right)$ dan hasil uji keberartian koefisien korelasi ganda dengan uji $\mathrm{F}$ yaitu $\mathrm{F}_{\text {hit }}: 7,23>\mathrm{F}_{\text {tabel }}:$ 4,74 dimana angka ini menunjukan angka yang signifikan. Hasil uji ini menyatakan bahwa $\mathrm{H}_{0}$ ditolak, $\mathrm{H}_{\mathrm{a}}$ diterima, dengan kata lain terdapat hubungan yang signifikan antara kecepatan $\left(\mathrm{X}_{1}\right)$ dan daya ledak otot tungkai $\left(\mathrm{X}_{2}\right)$ secara bersamasama dengan hasil lompat jauh (Y) dengan keeratan hubungan sangat kuat. Dari nilai $\mathrm{R}^{2}$ dapat disimpulkan bahwa kontribusi kecepatan dan daya ledak otot tungkai secara bersama-sama terhadap keberhasilan lompat jauh adalah sekitar 61,94\% - 67,07\%, dimana kontribusi ini cukup signifikan dalam menentukan keberhasilan dan peningkatan prestasi dalam lompat jauh.

\section{Pembahasan}

Syarifuddin (1992:90) mengemukakan, bahwa "lompat jauh adalah suatu bentuk gerakan melompat mengangkat kaki ke atas, ke depan dalam upaya membawa titik berat badan selama mungkin di udara (melayang di udara) yang dilakukan dengan cepat dan dengan jalan melakukan tolakan pada satu kaki untuk mencapai jarak yang sejauh-jauhnya". Disimpulkan, bahwa untuk mencapai lompatan yang maksimal dalam lompat jauh ditentukan oleh kemampuan kecepatan dan kekuatan tolakan (daya ledak). 
Kusyanto (1994:83) mengemukakan, bahwa "kecepatan adalah kemampu-an untuk melakukan gerakan-gerakan yang sejenis secara berturut-turut dalam waktu yang sesingkat-singkatnya, atau kemampuan untuk menempuh jarak dalam waktu yang sesingkat-singkatnya". Menurut Annarino dalam Arsil (1999), "daya ledak adalah kekuatan dan kecepatan kontraksi otot secara dinamis, eksplosif dalam waktu yang cepat".

Dari hasil penelitian terdapat hubungan yang signifikan antara kecepatan dengan hasil lompat jauh putra dan putri dengan nilai koefisien untuk putra $r=0,785\left(r^{2}: 0,6162\right)$ yang berarti bahwa kecepatan berkontribusi sebesar $61,62 \%$ terhadap hasil lompat jauh yang dicapai oleh siswa putra dengan keeratan hubungan kuat.

Kemudian nilai koofesien kecepatan untuk putri $r=0,759\left(r^{2}: 0,5761\right)$ yang berarti Kecepatan berkontribusi sebesar $57,61 \%$ terhadap hasil lompat jauh yang dicapai oleh siswa putri dengan tingkat keeratan hubungan kuat. Dari variabel daya ledak otot tungkai terlihat bahwa nilai koefesien untuk siswa putra $r=0,067\left(r^{2}: 0,0045\right)$ yang berarti bahwa daya ledak otot tungkai berkontribusi sebesar $0,45 \%$ terhadap hasil lompat jauh yang dicapai oleh siswa putra dengan keeratan hubungan lemah, kemudian nilai koofesien daya ledak otot tungkai untuk siswa putri $r: 0,436\left(r^{2}: 0,1900\right)$ yang berarti bahwa daya ledak otot tungkai berkontribusi sebesar 19,0\% terhadap hasil lompat jauh yang dicapai oleh siswa putri dengan keeratan hubungan sedang.

Dari hasil koefesien daya ledak otot tungkai putra dan putri ini menunjukkan bahwa tidak terdapat hubungan yang signifikan antara daya ledak otot tungkai dengan hasil lompat jauh. Sedangkan hubungan antara variabel kecepatan dan daya ledak otot tungkai secara bersama-sama dengan hasil lompat jauh putra dan putri merupakan hubungan yang kuat antara variabel bebas dengan variabel tak bebas dengan nilai koefisien korelasi ganda untuk putra $R: 0,819\left(R^{2}: 0,6707\right)$ berarti $67,07 \%$ dan nilai koefisien korelasi ganda untuk putri $\mathrm{R}: 0,787\left(\mathrm{R}^{2}: 0,6194\right)$ berarti $61,94 \%$.

Dengan kata lain terdapat hubungan yang signifikan antara kecepatan $\left(\mathrm{X}_{1}\right)$ dan daya ledak otot tungkai $\left(\mathrm{X}_{2}\right)$ secara bersama-sama dengan hasil lompat jauh putra dan putri (Y) dengan keeratan hubungan kuat. dimana kontribusi sebesar $67,07 \%$ untuk putra dan $61,94 \%$ untuk putri sangat signifikan terhadap keberhasilan dan peningkatan prestasi dalam lompat jauh. Berarti dapat di simpulkan 36,93\% untuk putra dan 38,06\% untuk putri terdapat faktor lain yang mempengaruhi hasil lompatan dari lompat jauh seperti teknik, program latihan dan sebagainya.

Berdasarkan penelitian yang telah dilakukan diperoleh tingkat kecepatan dan daya ledak otot tungkai siswa SMP Negeri 2 Lengayang Kabupaten Pesisir Selatan berada pada kategori sedang. Menurut Syarifuddin (1992:90), "Fase pada lompat jauh yang meliputi fase awal: ancang-ancang (gerakan awal), fase utama: menolak (take off), melayang sampai pada saat sebelum kaki mendarat, dan fase akhir: pendaratan sebagai". Ketiga fase tersebut dilaksanakan dalam bentuk suatu kesatuan urutan gerakan lompat yang sangat cepat dan berkelanjutan.

Awalan yang lebih panjang biasanya digunakan para atlit lompat jauh, karena atlit memulai lari dengan kecepatan rendah dan akan terus meningkatkan kecepatannya secara bertahap hingga mencapai kecepatan maksimum. Dikarenakan keberhasilan dalam melakukan lompat jauh bergantung pada kecepatan lari, maka pelompat jauh yang handal biasanya juga pelari jarak pendek yang bagus. Menurut Jensen et.al (1977),

"proses tinggal landas merupakan hasil dari kombinasi tiga gaya: (1) kecepatan saat lari awalan; (2) dorongan dari kaki; dan (3) aksi dorongan dengan ayunan kaki dan lengan.

Masing-masing gaya berkontribusi maksimum, dan harus tepat waktu. Kelompok otot utama yang terlibat dalam tahap tinggal landas ini adalah otot pinngul, lutut, dan pergelangan kaki”.

Selanjutnya, Jensen et.al (1977) juga menambahkan "walaupun sudut optimal dari proyeksi saat tinggal landas adalah sekitar $40^{\circ}$, namun kecepatan horizontal saat berlari pada fase awalan mengakibatkan kesulitan dalam memproyeksikan tubuh membentuk sudut yang lebih besar dari $30^{\circ}$ 
terhadap permukaan tanah". Kebanyakan pelompat jauh yang tidak terlatih cenderung kurang mampu melompat lebih tinggi. Agar lompatan ini bisa lebih tinggi, maka dibutuhkan daya ledak otot tungkai yang besar.

Konsep hukum kekekalan energi juga merupakan konsep penting dalam menjelaskan proses keberhasilan dalam lompat jauh ini. Menurut Giancoli (2001), "energi kinetik dari atlet yang berlari dan energi potensial elastis dari otot kaki saat melakukan tolakan pada papan tolakan diubah menjadi energi potensial gravitasi saat atlet meninggalkan tanah serta energi kinetik saat melakukan gerakan di udara (terbang)". Tolakan kaki menyumbang energi tambahan untuk dapat meningkatkan energi potensial gravitasi tubuh, sehingga atlet memliki waktu yang lebih lama di udara untuk dapat mencapai titik terjauh saat mendarat. Dengan begitu, daya ledak otot tungkai juga merupakan kondisi fisik yang harus terus dilatih dan ditingkatkan.

Dari hasil penelitian yang didapatkan, jelas terlihat bahwa kecepatan saat awalan berkontribusi signifikan terhadap hasil lompat jauh, sedangkan daya ledak otot tungkai tidak signifikan terhadap hasil lompat jauh. Hal ini disebabkan karena energi potensial yang dihasilkan daya ledak otot tungkai dengan arah pertikal belum dirubah menjadi energi kinetik yang dihasilkan oleh kecepatan lari menjadi energi potensial gravitasi dan energi kinetik untuk melakukan gerakan ke depan saat di udara.

Namun hal ini bukan berarti bahwa daya ledak otot tungkai bukanlah merupakan kondisi yang kurang penting, melainkan juga merupakan aspek yang menentukan dalam lompat jauh terutama untuk memproyeksikan tubuh sesuai dengan gambaran teori sebelumnya. Selanjutnya, Jensen et.al (1977) juga menjelaskan bahwa "aksi saat terbang digunakan untuk membantu keseimbangan dan menjaga posisi tubuh yang baik untuk mendarat. Pergerakan saat di udara tidak merubah sudut saat terbang atau memperpanjang terbang".

\section{KESIMPULAN}

Berdasarkan analisis data dari penelitian kontribusi kecepatan dan daya ledak otot tungkai terhadap hasil lompat jauh siswa SMP Negeri 2 Lengayang Kabupaten Pesisir Selatan tTerdapat hubungan yang signifikan antara kecepatan dengan hasil lompat jauh siswa putra. Nilai kontribusi kecepatan terhadap hasil lompat jauh putra adalah sebesar $61,62 \%$.

Selanjutnya tidak terdapat hubungan yang signifikan antara daya ledak otot tungkai dengan hasil lompat jauh putra yang tingkat keeratan hubungannya lemah. Nilai kontribusi daya ledak otot tungkai terhadap hasil lompat jauh putra adalah sebesar $0,45 \%$. Terdapat hubungan yang signifikan antara kecepatan dan daya ledak otot tungkai secara bersama-sama dengan hasil lompat jauh putra yang keeratan hubungannya kuat. Nilai kontribusi kecepatan dan daya ledak otot tungkai terhadap hasil lompat jauh putra adalah sebesar $67,07 \%$.

Sedangkan terdapat hubungan yang signifikan antara kecepatan dengan hasil lompat jauh siswa putri yang kontribusinya terhadap hasil lompat jauh adalah sebesar $57,61 \%$. Tidak terdapat hubungan yang signifikan antara daya ledak otot tungkai dengan hasil lompat jauh putri yang tingkat keeratan hubungannya sedang. Nilai kontribusi daya ledak otot tungkai terhadap hasil lompat jauh putri adalah sebesar $19,0 \%$. Terdapat hubungan yang signifikan antara kecepatan dan daya ledak otot tungkai secara bersama-sama dengan hasil lompat jauh putri yang keeratan hubungannya kuat. Nilai kontribusi kecepatan dan daya ledak otot tungkai terhadap hasil lompat jauh putri adalah sebesar $67,07 \%$.

Untuk itu kepada siswa putra dan putri SMP Negeri 2 Lengayang Kabupaten Pesisir Selatan yang mengikuti kegiatan ekstrakurikuler lompat jauh agar bisa meningkatkan tingkat kecepatan saat melakukan awalan dan daya ledak otot tungkai guna mendapatkan hasil lompatan yang lebih baik lagi. Bagi pembina kegiatan ekstrakurikuler lompat jauh di SMP Negeri 2 Lengayang Kabupaten Pesisir Selatan agar membuat program latihan khusus untuk peningkatan tingkat kecepatan siswa karna hubungan kecepatan dengan hasil lompat jauh cukup signifikan dengan tujuan mendapatkan hasil lompatan yang maksimal. Selanjutnya diharapkan kepada peneliti lain agar dapat melanjutkan 
penelitian ini, dengan melihat variabel-variabel lainnya yang berhubungan dengan tingkat kesegaran jasmani.

\section{DAFTAR RUJUKAN}

Adisasmita, Yusuf. 1992. Olahraga Pilihan Atletik. Jakarta: Departemen Pendidikan dan Kebudayaan.

Arikunto, Suharsimi. 1992. Prosedur Penelitian. Jakarta: Rineka Cipta.

Arsil. 1999. Pembinaan Kondisi Fisik. Padang: Fakultas Ilmu Keolahragaan Universitas Negeri Padang.

Asrul. 1998. Hubungan Antara Kemampuan Lari dengan Kemampuan Lompat Jauh Mahasiswa FIK UNP 2004. Skripsi S1 Jurusan Kepelatihan. Padang: Fakultas Ilmu Keolahragaan Universitas Negeri Padang.

Bafirman. 2006. Pembinaan Kondisi Fisik. Padang: Fakultas Ilmu Keolahragaan Universitas Negeri Padang.

Basirun. 2006. Kontribusi Daya Ledak Otot dan Kelentukan Terhadap Prestasi Lompat Tinggi di SMA N 1 Matur. Tesis. Padang: Universitas Negeri Padang.

Benhard, Gunter. 1986 . Prinsip Dasar Loncat Tinggi, Jauh, Jangkit, dan Galah. Semarang: Dahara Prize.

Dirjen Pendidikan Dasar dan Menengah. 1999. Materi Pelatihan Guru Pendidikan Jasmani dan kesehatan SD/Pelatih Klub Olahraga Usia Dini. Jakarta: Departemen Pendidikan dan Kebudayaan.

Carr, Gerry. 1986 . Atletik Untuk Sekolah. Jakarta: PT Rajagrafindo Persada.

Giancoli,C.Douglas. 2001. Fisika.Ed.5 Terj.Yuhilza Hanum. Jakarta:Erlangga

Ismaryati. 2008. Tes dan Pengukuran Olahraga. Surakarta: Lembaga Pengembangan Pendidikan (LPP) Universitas Sebelas Maret Press.

Jensen,R.Clayne, G.W.Schultz and B.L.Bangerter. 1977. Applied Kinesiology and Biomechanics. USA: McGraw-Hill.

Kiram, Yanuar. 1999. Belajar Motorik. Padang: DIP UNP.

Krempel, R. E. dan Haag, Jonath. 1987. Atletik. Jakarta: Rosda Jayaputra.

Kusyanto, Yanto. 1994. Penjaskes 1. Bandung: Ganexa Exact.

Menpora. 2005. Undang-undang RI No.3 Tahun 2005. Tentang Sistim Keolahragaan Nasional. Jakarta: Mentri Pemuda dan Olahraga. 
Muhidin, SA dan M. Abdurahman. 2007. Analisis Korelasi, Regresi, dan Jalur dalam Penelitian. Bandung: CV. Pustaka Setia.

Nurmai, Erizal. 2004. Atletik. Padang: Fakultas Ilmu Keolahragaan Universitas Negeri Padang.

Orientis. 2001. Perbedaan Awalan 30 Meter dan 20 Meter Terhadap Hasil lompat Jauh Siswa SLTP N 3 Arau Kab. Lima Puluh Kota. Padang: Fakultas Ilmu Keolahragaan Universitas Negeri Padang.

Sudjana. 1992. Metoda Statistika. Bandung: Tarsito.

Syafruddin. 1994. Pengantar Ilmu Melatih. Padang: Institut Keguruan Ilmu Pendidikan.

Jonath. 1987. Atletik. Jakarta: PT Rosda Jayaputra Anggota Ikapi.

Wilis, Ratna. 2003. Kontribusi Kecepatan Lari 50 Meter dan Daya Ledak Otot Tungkai Terhadap Prestasi Lompat Jauh. Tesis. Padang: Program Pasca Serjana Universitas Negeri Padang.

Zulhendra. 2001. Hubungan Panjang Tungkai dan Kekuatan Otot Tungkai Dengan Hasil Lompat Jauh Siswa SMA Negeri 1 Palembayan. Skripsi S1 Jurusan Kesehatan dan Rekreasi. Padang: Fakultas Ilmu Keolahragaan Universitas Negeri Padang. 